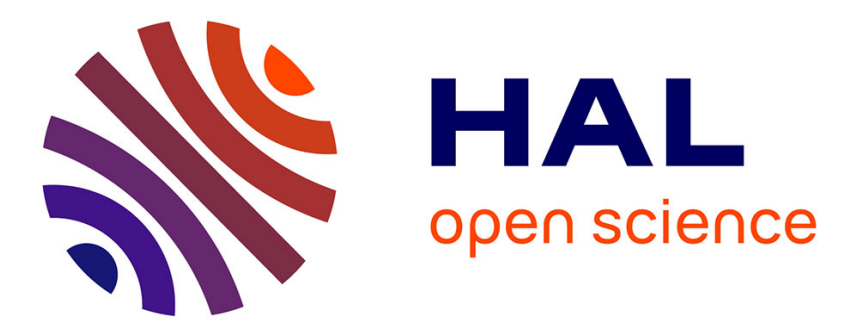

\title{
Up-scaling of crop productivity estimations using the AquaCrop model and GIS-based operations
}

\author{
Itidel Alaya, M. M. Masmoudi, Frédéric Jacob, N. Ben Mechlia
}

\section{To cite this version:}

Itidel Alaya, M. M. Masmoudi, Frédéric Jacob, N. Ben Mechlia. Up-scaling of crop productivity estimations using the AquaCrop model and GIS-based operations. Arabian Journal of Geosciences, 2019, 12 (14), 10.1007/s12517-019-4588-5 . hal-02617667

\section{HAL Id: hal-02617667 \\ https://hal.inrae.fr/hal-02617667}

Submitted on 3 Jun 2021

HAL is a multi-disciplinary open access archive for the deposit and dissemination of scientific research documents, whether they are published or not. The documents may come from teaching and research institutions in France or abroad, or from public or private research centers.
L'archive ouverte pluridisciplinaire HAL, est destinée au dépôt et à la diffusion de documents scientifiques de niveau recherche, publiés ou non, émanant des établissements d'enseignement et de recherche français ou étrangers, des laboratoires publics ou privés.

\section{(c)(1)}

Distributed under a Creative Commons Attribution| 4.0 International License 


\title{
Up-scaling of crop productivity estimations using the AquaCrop model and GIS-based operations
}

\author{
I. Alaya ${ }^{1,2} \cdot$ M. M. Masmoudi ${ }^{1} \cdot$ F. Jacob ${ }^{2} \cdot$ N. Ben Mechlia ${ }^{1}$
}

\begin{abstract}
Crop models are useful in evaluating management strategies and exploration of new practices, particularly in studies related to climate change and productivity assessment of agricultural systems. At field level, biophysical crop models are generally suitable in homogeneous environments when accurate input data and calibration parameters are available. However, their use at watershed level is limited, especially in hilly areas with great variability of soils, slope, and land use. Systematic method considering all terrain variabilities is time consuming since it requires high-resolution data and parameterization effort while geospatial models like SWAT, using simplified crop modules do not reflect the complexity of the simulated processes. In this work, an alternative methodology is proposed and tested in the hilly Mediterranean watershed of Kamech located in the Cap Bon Peninsula, Tunisia $\left(\mathrm{N} 36.88^{\circ}, \mathrm{E} 10.88^{\circ}\right)$; it uses the FAO AquaCrop biophysical model to estimate production in selected fields and scale up the results to the watershed level. Maps of soil, slope, and land use are combined by a GIS tool to obtain a database of averaged field properties and occupations. Three categories of texture, depths, and slopes were considered to classify the 313 fields of the watershed into 27 soil classes and determine their respective area-weighting factor. The systematic method considering all fields and the proposed method considering the 27 representative fields were used to estimate the watershed production for dominant crops: wheat, barley, and faba bean. Results show a good correlation between both methods with values of relative RMSD in the range of $0.5-2 \%$ for biomass and 2-5\% for grain yield. Decile-decile analysis showed that the proposed methodology simulated almost all the observed spatial variability of yield within the watershed suggesting its suitability for productivity assessment and prediction in hilly fragmented agricultural landscape.
\end{abstract}

Keywords Crop model $\cdot$ Production $\cdot$ Productivity $\cdot$ Soil properties $\cdot$ Hilly watershed $\cdot$ Scaling up $\cdot$ AquaCrop

\section{Introduction}

Global warming will probably affect all aspects of human activities, but its effects on food security are the most important and are a subject of intensive scientific research activities (Ewert et al. 2015a, b; Fischer et al. 2005; Kang et al. 2009; Parry et al. 2005; Rosenzweig and Parry 1994). Several

M. M. Masmoudi masmoudi.med@inat.agrinet.tn

1 University of Carthage, INAT, 43 Avenue Charles Nicolle, 1082 Tunis, Tunisia

2 IRD, UMR LISAH, 2 place Viala, 34060 Montpellier, France studies are carried out to predict the climate change impact on agricultural systems in order to identify adaptation and mitigation options (White et al. 2011; Yin 2013; Tubiello et al. 2000; Webber et al. 2014; Rosenzweig and Wilbanks 2010). Crop yields and productivity are forecasts which are usually estimated by means of statistical and empirical models. But the use of biophysical models in climate change studies is more adequate as they take into account environmental and management variables. Many lumped crop models have been developed and used during last few decades, e.g., EPIC (Williams et al. 1984; Brown and Rosenberg 1997; Farina et al. 2011; Mitter et al. 2015), CropSyst (Stöckle et al. 1994; Bocchiola et al. 2013; Giannakopoulos et al. 2009; Tubiello et al. 2000), DSSAT (Hoogenboom et al. 1995), STICS (Brisson et al. 2003; Butterworth et al. 2010; Leclere et al. 2013), and more recently the FAO AquaCrop model (Steduto et al. 2009; Voloudakis et al. 2015; Vanuytrecht et al. 2014). These models use different concepts 
and have different structures, scales, and levels of complexity. Their precision and accuracy vary widely across crops and sites (Tubiello and Ewert 2002; Campbell et al. 2016). As a general rule, good modelling practice consists in keeping models as simple as possible, but with enough incorporated details to capture the major processes that determine the system's behavior (Adam et al. 2011). The FAO crop model "AquaCrop" which requires a relatively small number of input parameters seems to respond to these criteria. Based on a water-driven growth engine, The FAO model is more suitable for water-limited environments. AquaCrop was calibrated and tested at field scale for many crops (Fereres et al. 2012) and used for different purposes including assessment of water productivity, yield gap, and irrigation scheduling (Heng et al. 2009; Araya et al. 2010; Andarzian et al. 2011) and in climate change impact studies (Mainuddin et al. 2011).

When used to assess climate change impact over large areas, lumped crop models are applied at higher aggregation levels which might reduce their efficiency. The resultant inaccuracy is namely related to inappropriate spatial resolution, low precision of input data, and misrepresentation of the system processes at large scale (Hoffmann et al. 2016; Scholten 2008; Van Bussel 2011). Extending from field scale to watershed is associated with an increase of weather, topography, and soil spatial variabilities. When input data are aggregated, this spatial heterogeneity is lost, which will affect the model's accuracy (Ewert et al. 2015a, b; Hansen and Jones 2000; Largani 2013). Uncertainty becomes highly significant for areas with large terrain heterogeneity and important farmland fragmentation.

The up-scaling is particularly problematic in Mediterranean hilly ecosystems, dominated by agricultural lands, evergreen woodlands, and maquis habitats, and characterized by high heterogeneity of soils, land fragmentation, and profound changes in vegetation cover due to the anthropogenic activities (Demetriou 2014; Geri et al. 2010; Sala et al. 2000).

Relief and soil heterogeneity are properly represented in distributed hydrological models (DHMs) which allowed the adequate representation of hydrological processes. Some DHMs integrated vegetation modules to simulate evapotranspiration for use in productivity assessment or irrigation management. With a simplified module of the crop model, SWAT DHM was used for optimal irrigation scheduling (Faramarzi et al. 2010) and for exploring the impact of irrigation on stream flow (Dechmi et al. 2012). It was also used to estimate water productivity and yield gap of some field crops (Huang and Li 2010; Schierhorn et al. 2014). However, its use in assessing climate change impact on production is limited although its crop module allows the increase of $\mathrm{CO}_{2}$ concentration which affects the radiation use efficiency and crop transpiration parameters (Butcher et al. 2014; White et al. 2011).
In productivity assessment and prediction studies, the choice between using complex and time-consuming DHMs, based on simplified crop models, or up-scaling results of dedicated biophysical crop models, depends on the available data and the level of precision needed, but remains problematic for highly heterogeneous watersheds.

In this work, we propose a simplified approach based on the use of AquaCrop and straightforward up-scaling method combining terrain variables and land use. All fields of the watershed are classified into a limited number of classes according to slope, soil texture, and soil depth. The weight of each class within the cropped area is determined for dominant crops using land use maps and a GIS tool. Crop productivity is estimated by the AquaCrop model for all fields and in one representative field of each soil class. Watershed productivity is calculated by 2 methods: the reference method using results of all fields and the proposed method using only results of the representative fields affected by their corresponding weighting factor values.

The proposed method is tested in a hilly agricultural watershed, characterized by a strong fragmentation and significant terrain variability. Results of the simplified approach are compared with those obtained by the systematic approach that considers all fields.

\section{Materials and methods}

\section{Study area}

A small hilly agricultural watershed, Kamech $\left(2.63 \mathrm{~km}^{2}\right)$, located in the Cap Bon Peninsula in north-east of Tunisia (N $36.88^{\circ}, \mathrm{E} 10.88^{\circ}$ ) is considered in this study. Its climate is Mediterranean sub-humid characterized by warm and dry summers and mild and relatively rainy winters (Ben Mechlia et al. 2008; Inoubli et al. 2017). Average annual rainfall in the region is about $620 \mathrm{~mm}$ with a coefficient of variation of $27 \%$, and the mean annual reference crop evapotranspiration (ETo) during the period (2004-2013) is around $1200 \mathrm{~mm}$ (OMERE 2017).

The area is marked by contrasted landscape characteristics and strong fragmentation. More than $70 \%$ of the watershed land use is agricultural covering 331 fields. The watershed is characterized by intensive agricultural activity with the dominance of annual crops: cereals and pulses. The main cultivated cereals are wheat, barley, and oats whereas for pulses, the major cultivated species are faba bean and chickpea. The remaining $30 \%$ of the catchment's area is pasture composed of grassland and low Mediterranean scrublands that cover generally the steepest parts of the watershed (Ben Mechlia et al. 2008; Mekki et al. 2018).

According to the FAO classification (2006), the soil classes present in the watershed are calcic Cambisols, Regosols, 
eutric Regosols, and Vertisols (Ben Slimane 2013; Inoubli 2017). The soil depth varies between very shallow (few centimeters) covering the sandstone bars and very deep $(2 \mathrm{~m})$ for soils developed on the marly substrate (Mekki 2003; Morschel 2010). The presence of alternating sandstones and marls induces a variability of soil texture that ranges from clay to sandy loam. Slopes range between 0 and $30 \%$ but more than the half of the area is characterized by a low or moderate slope $(<10 \%)$. The watershed is marked by irregular slopes especially on the southern edge (Ben Mechlia et al. 2008; ZitounaChebbi et al. 2018).

\section{Datasets and used maps}

The available data on soil are the soil map of Zante et al. (2005) which contains descriptive soil units and some quantitative data about soil profiles realized locally (IAO 2002; Mekki 2003; Alaya et al. 2017). Quantitative information on texture, wilting point, field capacity, and hydraulic conductivity at saturation needed by AquaCrop are available for only a limited number of fields. We used the pedotransfer functions to derive these properties for all soil units from the soil description in the soil map and the available quantitative data. The Saxton and Rawls' (2006) pedotransfer functions were adopted for this task as they were evaluated in a previous work for the soils of the region and showed a good performance in estimating field capacity and permanent wilting (Alaya et al. 2017). Soil class depth is derived from soil map. The information concerning texture, bulk density, hydraulic properties, and depth are then added to each unit of the soil map. The resulting shapefile was combined with the fields' ownership map to determine mean values for each field. A 10-m digital elevation model is used with the QGIS software to map the watershed slopes and to calculate the average slope of each field.

Land use maps are available for 13 seasons between 1996 and 2012 (Mekki 2003; OMERE 2017) with heterogeneous field limits and legend. Those corresponding to the period 1996-2001 contain only general information about fields' occupation, namely cereals, pulses, arboriculture, grassland, and scrublands while the survey for the period 2004-2012 delineates the cultivated species and their area limits when more than one species are cultivated on a field.

Land use maps were used to identify the dominant cultivated crops, the change of their areas, and the crop rotations practiced in each field. Then, they were homogenized and combined into a single shapefile with information on field limits and legend, used in a representative field selection procedure.

Daily climatic data observed at the watershed by the Mediterranean environmental and water resources observatory (OMERE) during the period 2004-2013 were used to determine reference evapotranspiration by the PenmanMonteith method and used in the simulations.

Field observations carried out in 2009-2010 and 20122013 on wheat barley were used for AquaCrop model evaluation (Aloui et al. 2012; Boudhina et al. 2019).

\section{The proposed up-scaling methodology}

Two methods were applied to estimate watershed crop production using the site-based model "AquaCrop." The first, considered as reference, is a systematic method consisting in simulating crop growth and production of all fields assuming homogeneous soil type, depth, and slope within each field. The watershed production is taken as the sum of production of all fields.

In the second method, a sample of small number of fields representative of all soil situations in terms of slope, depth, and texture is considered. Three levels of slope, texture, and depth were used to classify all fields in the watershed resulting potentially in 27 soil classes (Table 1).

The soil classification method is adapted from Sys et al. (1991) and Ben Mechlia et al. (2009) using quantitative thresholds for depth and slope and descriptive levels for texture (Table 1). Texture is determined according to the USDA soil textural classification (Soil Survey Staff 1951) that contains 12 classes. In order to facilitate the classification task in this study, we divided those classes into three groups (fine, medium, and coarse). We considered that fine textures are clay (C), sandy clay $(\mathrm{SaC})$, silty clay $(\mathrm{SiC})$, clay loam $(\mathrm{CL})$, and silty clay loam ( $\mathrm{SiCL})$. The medium texture group includes sandy clay loam (SaCL), loam (L), silty loam (SiL), silt, and sandy loam $(\mathrm{SaL})$ classes. The coarse texture covers loamy sand (LSa) and sand ( $\mathrm{Sa}$ ) classes.

The share of each soil class within the cropped area, representing its weight, is determined for cereal-dominant and pulse-dominant rotations using the homogenized average land use map. This weighting factor is defined for each crop and soil class as the ratio of the total area of the soil class over

Table 1 Criteria used for classification of soils in the watershed

\begin{tabular}{lll}
\hline Properties & Categories & Criteria \\
\hline Slope & Low & $0-5 \%$ \\
& Moderate & $5-10 \%$ \\
& Strong & $>10 \%$ \\
Depth & Shallow & $<60 \mathrm{~cm}$ \\
& Moderately deep & $60-100 \mathrm{~cm}$ \\
Texture & Deep & $>100 \mathrm{~cm}$ \\
& Fine & $\mathrm{C}, \mathrm{SaC}, \mathrm{SiC}, \mathrm{CL}, \mathrm{SiCL}$ \\
& Medium & $\mathrm{SaCL}, \mathrm{L}, \mathrm{SiL}, \mathrm{Si}, \mathrm{SaL}$ \\
& Coarse & $\mathrm{Sa}, \mathrm{LSa}$ \\
\hline
\end{tabular}


the total area cultivated by the crop. One representative field of each soil class is then selected and used to run the AquaCrop simulation model for wheat, barley, and faba bean. Results obtained in representative fields are therefore affected by their weighting factors and used to up-scale field productivities to the watershed level.

Both the exhaustive and the simplified methods are applied to estimate the watershed production of wheat, barley, and faba bean during the period 2004-2013.

\section{Crop growth model "AquaCrop"}

Being developed as a water-driven crop model, AquaCrop is considered an operational simulation model for areas where water is the main production limiting factor, especially in arid and semi-arid regions (Steduto et al. 2009; Yuan et al. 2013). AquaCrop input data and parameters are classified into four categories: weather, crop, soil, and management practices. The input data for these four components are used to simulate soil water balance and the green canopy expansion change over time. One of the main features of AquaCrop is the separation of evapotranspiration into soil evaporation and crop transpiration processes (Vanuytrecht et al. 2014).

The canopy growth is simulated using the green canopy cover concept (CC) instead of leaf area index (LAI). The advantage of using $\mathrm{CC}$ is that it can be strongly correlated with data derived from remote sensing such as vegetation indices, mainly NDVI. Such indices simplify the calibration and validation task over large areas (Kim and Kaluarachchi 2015; Foster et al. 2017). The above ground biomass is simulated as the product of the normalized water productivity (WP*) and cumulative transpiration during the biomass production period. Water productivity is a conservative, crop-specific parameter. Its values are standardized for evaporative demand of the atmosphere (ETo) and $\mathrm{CO}_{2}$ concentrations, which give the model the ability to be used in climate change studies considering different scenarios and locations. The yield production is linked to the total biomass via a harvest index adjusted to the timing and extent of water or temperature stress during the crop cycle (Hsiao et al. 2009; Steduto et al. 2009; Raes et al. 2009). In addition to water stress, AquaCrop considers other environmental factors including heat stress, soil salinity stress, and soil fertility stress. Water stress effects are simulated for three main processes namely leaf expansion, stomatal closure, and early canopy senescence that determine the amount of water transpired and thus the amount of biomass produced (Van Gaelen 2016; Vanuytrecht et al. 2014).

\section{Statistical evaluation}

The statistical indicators used in performance evaluation are the coefficient of determination $\left(R^{2}\right)$, the root mean squared difference (RMSD), the relative root mean squared deviation (rRMSD), and the Willmott trend index (d) given in Eqs. 1 to 4.

$R^{2}=\frac{\sum_{i=1}^{n}\left(P_{i}-\bar{O}\right)^{2}}{\sum_{i=1}^{n}\left(O_{i}-\bar{O}\right)^{2}}$

$R M S D=\left\{\frac{1}{n} \times \sum_{i=1}^{n}\left(P_{i}-O_{i}\right)^{2}\right\}^{1 / 2}$

$r R M S D=\left\{\frac{1}{n} \times \sum_{i=1}^{n}\left(P_{i}-O_{i}\right)^{2}\right\}^{1 / 2} \times \frac{100}{\bar{O}}$

$d=1-\frac{\sum_{i=1}^{n}\left(P_{i}-O_{i}\right)^{2}}{\sum_{i=1}^{n}\left(\left|P_{i}-\bar{O}\right|+\left|O_{i}-\bar{O}\right|\right)^{2}}$

where $P_{i}$ represent the watershed production during year "i" determined by the proposed up-scaling methodology considering the extrapolated results of the 17 sample fields of cereals and 14 fields of pulses; $O_{i}$ is the watershed production obtained during year $i$ by the systematic method considering the production of all fields.

The coefficient of determination $\left(R^{2}\right)$ is a measure of the variability explained by the model. The root mean square difference is a measure of the average deviation between the proposed and the systematic methods. The rRMSD is a dimensionless criterion that expresses error as a fraction of average value, which is more convenient for comparing errors based on different datasets with different average responses. Model performance can be classified according to rRMSD values as excellent $(<10 \%)$, good $(10-20 \%)$, fair $(20-30 \%)$, and poor (>30\%) (Van Gaelen 2016).

The Willmott trend index developed as a standardized metrics is a measure of model precision (Wilmott 1981) and varies between 0 and 1 (Holzkämper et al. 2015).

These statistical performance indicators, generally used in modeling tasks, were used by Hsiao et al. (2009), Andarzian et al. (2011), Voloudakis et al. (2015), and El Mokh et al. (2017) to evaluate the AquaCrop performance by comparing observed and simulated results. In the present work, the comparison concerns results obtained for the 10 years by the systematic method considering all fields, used as reference, and the proposed method using a sample of 17 fields of cereals and 14 fields of pulses.

\section{Results}

\section{In situ validation of the AquaCrop model}

Performance of AquaCrop is tested for wheat and barley using in situ monitoring data carried out in 2009/2010 by Aloui et al. (2012). During this experiment, agronomic observations were 
carried out in three fields of wheat and a single field of barley. Data from experimental field monitoring obtained by Boudhina et al. (2019) in three fields of wheat during 2013 were also considered for model verification. Simulation by AquaCrop was performed using observed climatic data and calibrated parameters of Sghaier et al. (2014) for wheat and El Mokh et al. (2017) for barley given in Table 2.

Figure 1 gives a comparison between observed and simulated values of total biomass. Linear regression between observed and simulated values shows that yields simulated by the model are overestimated for wheat and underestimated for barley. Determination coefficient $\left(R^{2}\right)$ between simulated and observed values was 0.82 for wheat and 0.90 for barley.

The Wilmott index values were 0.91 for wheat and 0.86 for barley indicating a good performance of the model. However, RMSD and rRMSD were relatively high; rRMSD value exceeds $50 \%$ for both crops, and RMSD value was $2.6 \mathrm{t} / \mathrm{ha}$ for wheat and $1.8 \mathrm{t} / \mathrm{ha}$ for barley. The difference is probably due to the use of crop and productivity parameters calibrated in Mornag and Medenine which have different climatic conditions from the study area particularly temperature and wind velocity. The use of different variety and crop management practices may also be the source of this difference. However, the use of a simple correction factor for "AquaCrop" output is possible as there is a good linear correlation between observed and simulated values.

\section{Selection of representative fields}

Analysis of soil and land use maps relative to the period 2004 2013 showed that cropped area represents $71 \%$ of the watershed surface with $49 \%$ occupation with cereals and $16 \%$ with pulses. The watershed is highly fragmented: $50 \%$ of the 331 fields are under 1 ha area with an average field size of 0.6 ha. In average, cereals are grown on 226 fields and cover 141 ha while pulses are present in 87 fields covering a total area of 45 ha

The application of the classification criteria (Table 1) on the watershed's slope, depth, texture layers, and land use maps showed that only 17 classes are present in the watershed for cereals and 14 classes for pulses (Table 3).

Cereals are mainly cultivated (46\%) on fine-to-medium textured and moderately deep sloping areas $(60-100 \mathrm{~cm}$
Table 2 Conservative and generally applicable parameters of the Crop Data file of AquaCrop, with values used for the simulation of wheat, barley, and faba bean productivity in Kamech watershed, Cap Bon, Tunisia

\begin{tabular}{|c|c|c|c|}
\hline & Wheat & Barley & Faba bean \\
\hline \multicolumn{4}{|l|}{ Conservative parameters } \\
\hline Base temperature $\left({ }^{\circ} \mathrm{C}\right)$ & 0.0 & 0.0 & 5.5 \\
\hline Cutoff temperature $\left({ }^{\circ} \mathrm{C}\right)$ & 26.0 & 28.0 & 30.0 \\
\hline Canopy cover per seedling at $90 \%$ emergence $(\mathrm{CCo})\left(\mathrm{cm}^{2}\right)$ & 1.50 & 1.50 & 5.00 \\
\hline Canopy growth coefficient (CGC) (in fraction CC per GDD) & 0.0052 & 0.0048 & 0.0105 \\
\hline Maximum canopy cover $(\mathrm{CCx})$ in fraction soil cover & 0.99 & 0.99 & 0.80 \\
\hline Crop coefficient for transpiration at $\mathrm{CC}=100 \%$ & 1.1 & 1.1 & 1.1 \\
\hline Decline in crop coefficient after reaching $\mathrm{CCx}(\% /$ day $)$ & 0.15 & 0.15 & 0.15 \\
\hline Canopy decline coefficient (CDC) (in fraction per GDD) & 0.0040 & 0.0032 & 0.0080 \\
\hline Water productivity normalized for ETo and $\mathrm{CO} 2(\mathrm{WP} *)\left(\mathrm{g} / \mathrm{m}^{2}\right)$ & 13.4 & 13.0 & 13.0 \\
\hline Leaf growth threshold $\left(\mathrm{P}_{\text {upper }}\right)$ & 0.20 & 0.20 & 0.25 \\
\hline Leaf growth threshold $\left(\mathrm{P}_{\text {lower }}\right)$ & 0.65 & 0.65 & 0.60 \\
\hline Leaf growth stress coefficient curve shape & 5.0 & 3.5 & 3.0 \\
\hline Stomatal conductance threshold $\left(\mathrm{P}_{\text {upper }}\right)$ & 0.65 & 0.65 & 0.60 \\
\hline Stomata stress coefficient curve shape & 2.5 & 3.0 & 3.0 \\
\hline Senescence stress coefficient $\left(\mathrm{P}_{\text {upper }}\right)$ & 0.70 & 0.75 & 0.75 \\
\hline Senescence stress s coefficient curve shape & 2.5 & 3.5 & 3.0 \\
\hline \multicolumn{4}{|l|}{ Non-conservative parameters } \\
\hline GDD from sowing to emergence & 140 & 151 & 122 \\
\hline GDD from sowing to maximum rooting depth & 1670 & 1467 & 741 \\
\hline GDD from sowing to start senescence & 1861 & 1820 & 1286 \\
\hline GDD from sowing to maturity (length of crop cycle) & 2777 & 2549 & 1411 \\
\hline GDD from sowing to flowering & 1543 & 1488 & 879 \\
\hline Length of the flowering stage (GDD) & 189 & 680 & 128 \\
\hline GDD building up of harvest index during yield formation & 980 & 899 & 495 \\
\hline Reference harvest index (HIo) (\%) & 45 & 38 & 30 \\
\hline
\end{tabular}




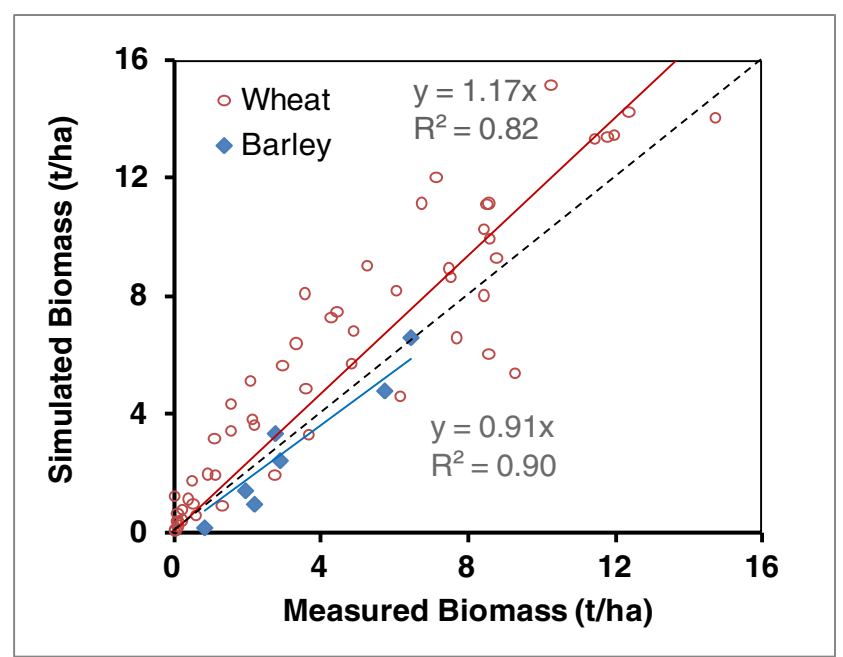

Fig. 1 Simulated vs. measured biomass for wheat and barley during 2009-2010 and 2012-2013

depth, $<10 \%$ slope) while $88 \%$ of pulses are cultivated in sloping fields ( $>5 \%$ slope).

One field was selected for each soil class and for each crop, and its properties were used as input parameters for the AquaCrop model. The model was used to simulate crop development and production of wheat, barley, and faba bean for the selected fields during ten seasons, i.e., 2004-2013. Figure 2 shows the distribution of the different occupations and the location of the selected fields on the watershed.

\section{Simulation of the watershed production}

An R script (R core Team 2016) was written and used to generate for all fields' input files required by AquaCrop: crop and soil parameter files, soil water initial condition files, and simulation projects. Simulation was performed using the AquaCrop plug-in in continuous run mode for 10 years (2004-2013) to take into account the soil water content variations in the offseason. For each simulation project, AquaCrop generates two

Table 3 Share (\%) of each soil class in terms of texture, slope and depth within cereal-dominant and pulses-dominant (in parenthesis) cropped area in the watershed of Kamech, Cap bon-Tunisia, 2004-2013.

\begin{tabular}{|c|c|c|c|c|c|c|}
\hline Depth $(\mathrm{cm})$ & Texture & Slope: & $<5 \%$ & $5-10 \%$ & $>10 \%$ & $\begin{array}{l}\text { Total } \\
\text { share(\%) }\end{array}$ \\
\hline & Fine & & $4(0)$ & $4(6)$ & $5(9)$ & \\
\hline \multirow[t]{3}{*}{$<60$} & Medium & & $3(3)$ & $7(13)$ & $6(5)$ & $31(37)$ \\
\hline & coarse & & $1(0)$ & $0(0)$ & $1(1)$ & \\
\hline & Fine & & $13(3)$ & $18(22)$ & $14(12)$ & \\
\hline \multirow[t]{3}{*}{$60-100$} & Medium & & $8(3)$ & $7(5)$ & $5(11)$ & $65(56)$ \\
\hline & coarse & & $0(0)$ & $0(0)$ & $0(0)$ & \\
\hline & Fine & & $0(0)$ & $0(0)$ & $0(0)$ & \\
\hline \multirow[t]{2}{*}{$>100$} & Medium & & $1(3)$ & $2(4)$ & $1(0)$ & $4(7)$ \\
\hline & coarse & & $0(0)$ & $0(0)$ & $0(0)$ & \\
\hline Total share(\%) & & & $29(12)$ & $39(50)$ & $32(38)$ & $100(100)$ \\
\hline
\end{tabular}

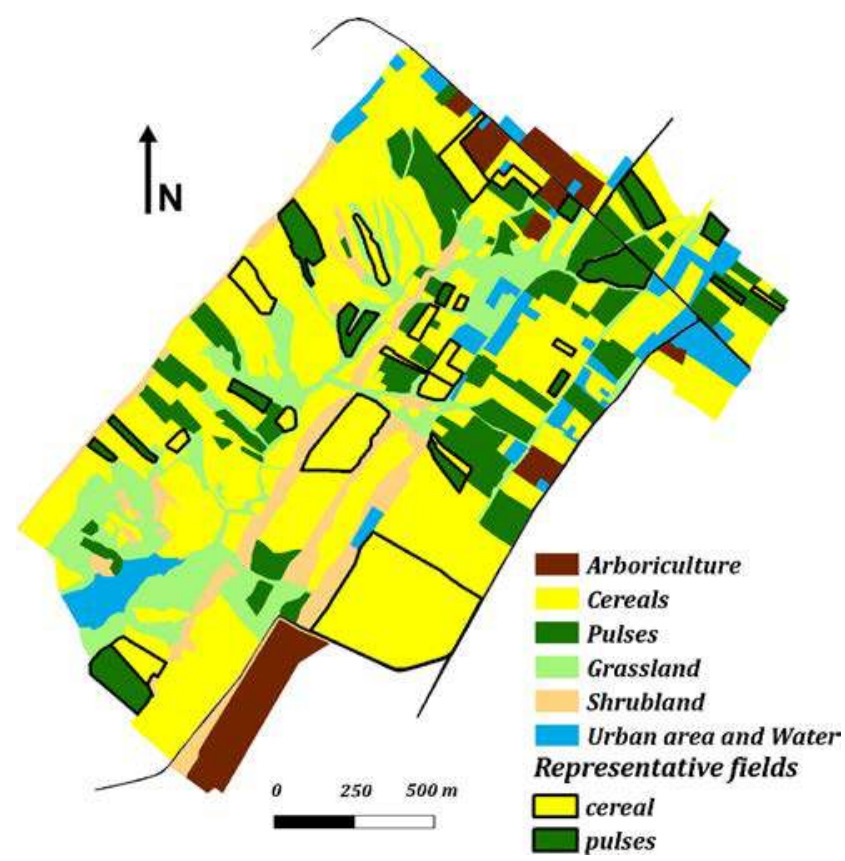

Fig. 2 Average watershed occupation map showing dominant crops during the period 2004-2013 and the selected representative fields of each soil category (outlined fields)

output files with daily and seasonal output data. A second $\mathrm{R}$ script was written and used to summarize the results of the output files and up-scale field results to the watershed.

The model was run for wheat, barley, and faba bean crops on all fields of the considered occupation category.

Figure 3 shows the patterns of grain yield of wheat simulated in the 226 fields and in the 17 selected sample fields. A significant inter-annual and spatial variation is observed in the watershed during the period 2004-2013 (Fig. 3a). Similar spatial and temporal variations are present in Fig. $3 b$ corresponding to the 17 selected fields, indicating the adequacy of the selection procedure of representative fields based on slope, and soil depth and texture. The same behavior is observed for faba bean and barley.

Spatial variability of yields was analyzed by means of deciles. Among the 226 fields of cereals, the second decile D2, representing the lowest $20 \%$ yields, varied during the period 2004-2013 between 6.6 and $12.5 \mathrm{t} / \mathrm{ha}$ for watershed averaged biomass and between 0 and $3.8 \mathrm{t} / \mathrm{ha}$ for watershed averaged grain yield (Fig. 4a). The decile D9 range was 10.8-15.7 t/ha for biomass and 3.6-6.3 tha for grain yield during the same period.

Simulation results for barley show more stability in production over the 10 cropping seasons. The 9th decile is between 9.6 and $13.2 \mathrm{t} / \mathrm{ha}$ for biomass and between 3.4 and $4.8 \mathrm{t} /$ ha for yield. For faba bean, the predicted production is also marked by a significant fluctuation. The median value of faba bean grain yield varied between 0.2 and $1.6 \mathrm{t} / \mathrm{ha}$ during the period 2004-2013 (Fig. 4b). 
Fig. 3 Patterns of grain yield in all wheat (226) fields of the watershed (a) and in the 17 selected fields (b) during the period 2004 2013

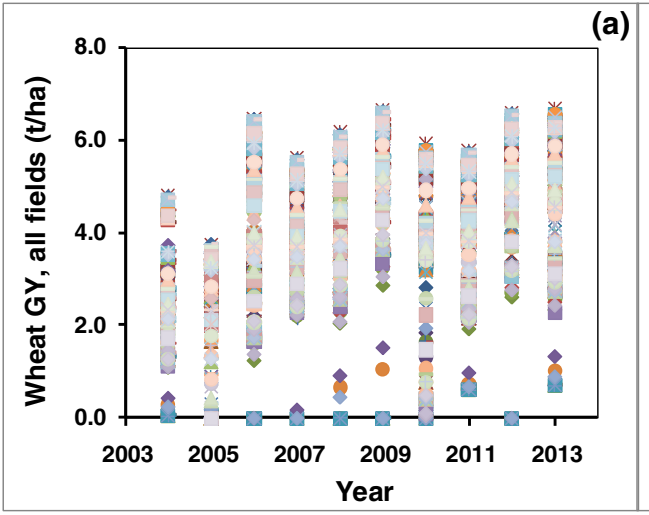

(a)

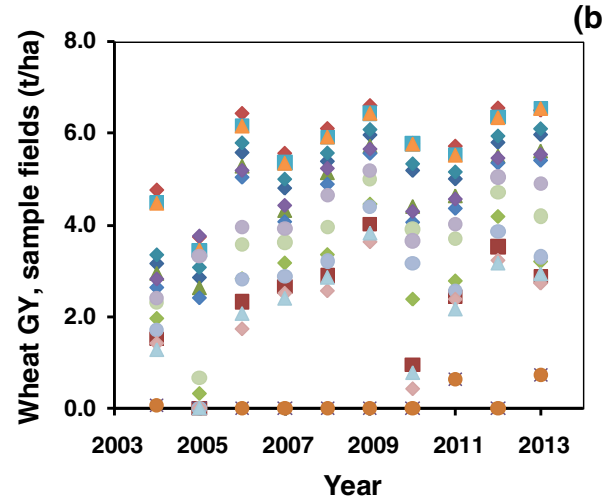

The average yield of the watershed was estimated by the systematic method which considers the production of the watershed as the sum of the productions of all fields and by the proposed up-scaling method which considers only the results of the 17 representative fields of cereals and the 14 fields of pulses to estimate the watershed production using weighting factor of each soil class.

Figure 5 compares watershed average yield estimated by both methods during the period 2004-2013 for wheat, barley, and faba bean. The proposed method, considering only a reduced number of representative fields, shows approximately a similar variations and similar decile distribution (Fig. 6) suggesting that the selected samples capture the spatial variability for both biomass and grain yield.

The variability of yields between soil classes is related to rainfall intensity and distribution during the season and soil depth and texture. The highest-yielding classes are deep soils with fine texture having large water holding capacity.

\section{Performance of the up-scaling method}

Graphical plots and statistical indicators were used for the comparison of watershed averaged biomass and grain yields estimated by the two methods (Fig. 5). A good correlation was obtained for the three crops.

The coefficient of determination $\left(R^{2}\right)$ and the slope of the linear regression line between estimated values by both methods are around 1 for the three considered crops. The root mean square difference (RMSD) for biomass and grain yield, given in Table 4, shows a good performance of the proposed methodology with a relative difference between 0.5 and $4.7 \%$.

The variability of yield within the watershed is analyzed through the decile-decile representation between both upscaling methods. Figure 6 shows that the selected fields captured the variability of soil characteristic within the watershed that determines productivity.

However, for wheat, a difference is observed for the first decile D1, which is found to correspond to shallow soils. The proposed method underestimates the production for this class. The selected fields representing these soils fail to reproduce all the variability of yield showing more sensitivity of the model to water holding capacity and to the rainfall temporal distribution. Even a minor raise of the soil depth in this group or a favorable rainfall distribution could have an important effect on yield. However, since this group has a small area and proportion of the total area, its contribution to the total production of the watershed is not significant.

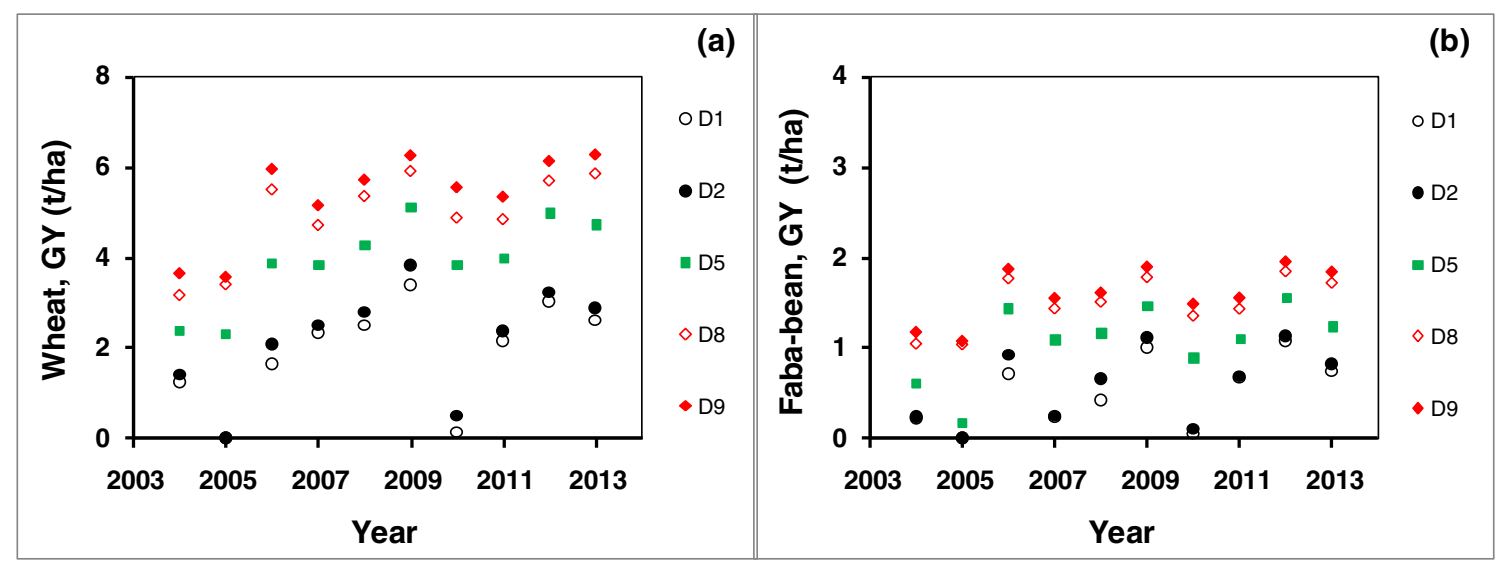

Fig. 4 Time course of grain yield deciles (D1...D9) corresponding to all fields of wheat (a) and faba bean (b) showing a large temporal and spatial variability of grain yield within the watershed 
Fig. 5 Comparison of watershed averaged biomass (B) and grain yield (GY) of wheat, barley, and faba beans estimated by the systematic method considering all fields and the proposed methodology considering a sample of representative fields, period 2004-2013

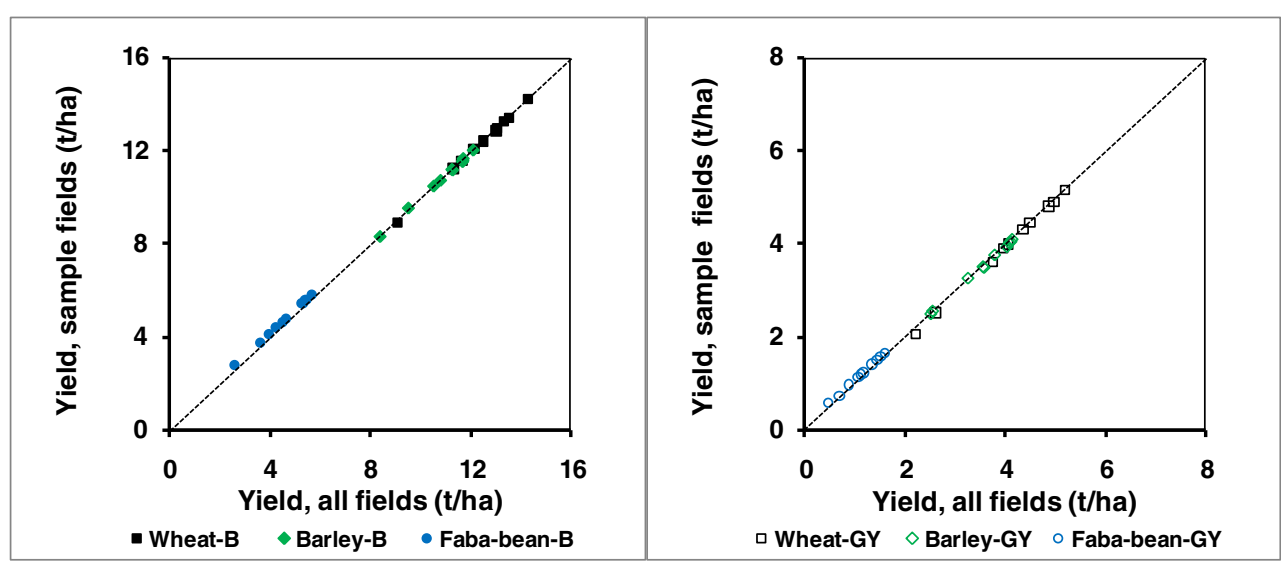

\section{Summary and discussion}

Estimation of agricultural productivity by lumped biophysical crop models is reported to be highly sensitive to the accuracy of weather, crop, and soil data. Up-scaling to watershed level can be performed by applying lumped crop model on all fields of the watershed or using distributed GIS-based models. This task is time and effort consuming particularly in fragmented hilly watersheds where high-resolution and accurate data is lacking. The present work tried to develop an alternative method where soils of the watershed were classified into 27 typical classes based on texture, slope, and depth and representativeness in the watershed is expressed as weighing factor.

Analysis of land use of the considered watershed during 13 cropping seasons showed that in average, cropped area covers $71 \%$ of the watershed area and that $70 \%$ and $22 \%$ of the cropped area are occupied respectively by cereals and pulses. Cereals are present on only 17 soil classes and pulses on only 14 soil classes among the 27 potential classes. Relative weights of soil classes were in the range $0.3-18.2 \%$ for cereals and $0.8-22.7 \%$ for pulses.

Simulation results of AquaCrop in the typical 17 and 14 fields were up-scaled to the watershed using the weighing factor of each soil class representing its share in the total cropped area. Results for the 10 cropping seasons for cereals and pulses are compared with those obtained by the reference method considering all fields and their respective soil properties.

Both methods showed approximately similar variations and similar decile distribution for biomass and yield suggesting that the adopted soil classification captured almost all the spatial variability. The estimations of crop production of the hilly watershed using the representative sites are highly correlated with those estimated by the systematic method considering all fields individually. Adopting the proposed methodology in our case reduced drastically simulation effort and time since only 17 fields over 226 and 14 over 87 were considered respectively for cereals and pulses. Relative difference between the proposed methodology and the systematic method did not exceed $2 \%$ and $5 \%$ for grain yield and $0.6 \%$ and $2.2 \%$ for total biomass respectively for cereals and pulses. The RMSD values for the watershed averaged yields are less than $0.1 \mathrm{t} / \mathrm{h}$ a for both species. The decile-decile plot shows that the proposed method captures the yield variability in the watershed, except for wheat on marginal shallow soil classes.

The obtained results should be compared with those using other approaches. Many platforms and models used in hydrologic studies allow the simulation of watershed hydrologic processes using distributed mechanistic or semi-empirical models and GIS tools, but the crop module of such packages
Fig. 6 Decile-decile plot between grain yields $(\mathrm{GY})$ estimated using the results of all fields and those using the sample fields of wheat (a) and faba bean (b) during the period 2003-2013

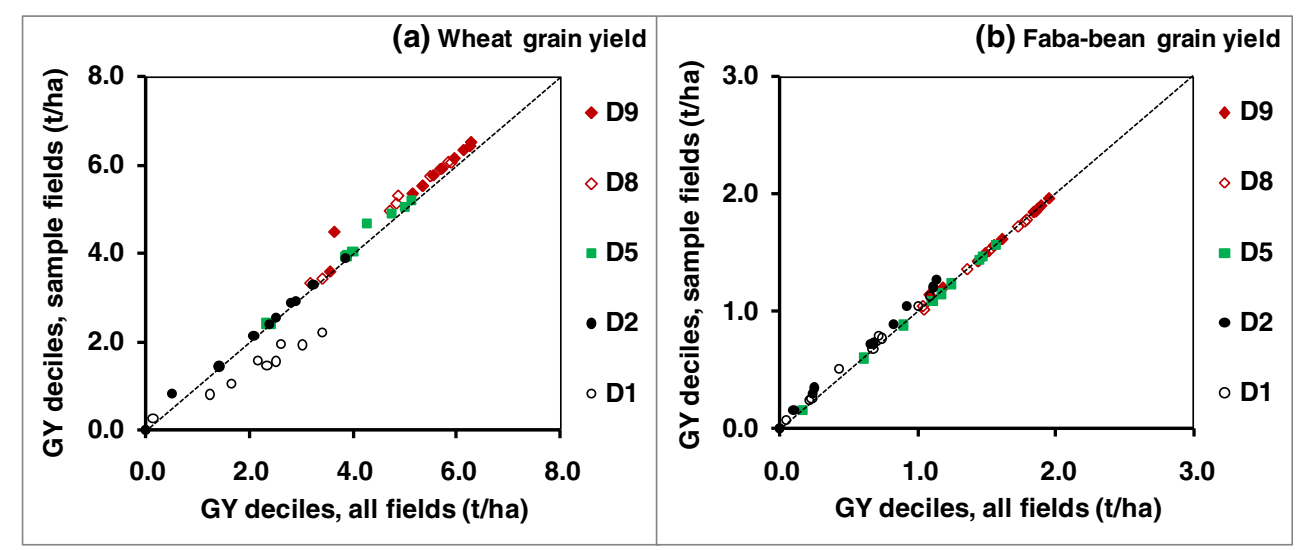


Table 4 Statistical measures of discrepancies (RMSD and rRMSD) for both systematic and the proposed methods used to determine crop biomass and grain yields of the watershed

\begin{tabular}{|c|c|c|c|c|c|c|}
\hline & \multicolumn{3}{|c|}{ Biomass } & \multicolumn{3}{|c|}{ Grain yield } \\
\hline & Wheat & Barley & Faba bean & Wheat & Barley & Faba bean \\
\hline$R^{2}$ & 0.99 & 0.99 & 0.99 & 0.99 & 0.99 & 0.98 \\
\hline RMSD (t/ha) & 0.07 & 0.05 & 0.10 & 0.08 & 0.04 & 0.05 \\
\hline rRMSD (\%) & 0.6 & 0.5 & 2.2 & 2.0 & 1.2 & 4.7 \\
\hline
\end{tabular}

is always empirical and does not account for $\mathrm{CO}_{2}$ concentration. The use of more dedicated biophysical models like AquaCrop requires a lot of efforts to prepare data for all fields in appropriate file format. Development of tools to automate the management of data and parameter files and to control the simulation runs in AquaCrop-GIS package introduces spatial dimension to the presentation of the model's results (Lorite et al. 2013, 2015). AquaCrop-GIS tool has been designed to facilitate the use of the AquaCrop model when a high number of simulations are needed, simplifying the task of generating input and project files and the management of output files. It prepares the required inputs, executes AquaCrop, elaborates the results, and shows them in a geographic information system.

AquaCrop-GIS allows a drastic reduction of processing time, but preliminary work to build data and parameter files remains an important and time-consuming task. Also, the lumped nature of the model remains as the connectivity of hydrologic variables between polygons is not implemented. Recent development of an open-source version of the model AquaCrop-OS (Foster et al. 2017) which will give the possibility of integrating the AquaCrop model with geospatial distributed hydrologic models and to use remote sensing data (Jin et al. 2016; Panday 2014), will likely contribute to improve model's accuracy (Han et al. 2019).

\section{Conclusion}

The proposed methodology, based on the use of AquaCrop and the classification/aggregation of topographic and soil properties for estimating productivity of hilly, highly fragmented watersheds, gave reasonably good results in comparison with the systematic method considering all fields and their actual soil properties. Its use for long-term simulation of productivity and its performance in climate change studies should be considered with reference to the more complex and time-consuming GIS-based models using lumped crop models like AquaCrop-GIS or the semi-distributed hydrological model like SWAT. The recent release of an open-source version of AquaCrop which can be run on multiple programming languages and operating systems and support parallel execution will certainly facilitate the model linkage and integration in distributed hydrological models for a better simulation of both crop and hydrologic processes. Connection with remotely sensed data could also be considered in watershed productivity assessment applications as it allows the use of actual land occupation and crop cover percentage used for partitioning evaporation/transpiration variables.

Acknowledgments The support of the French Institute of Research for Development (IRD), the Institut National Agronomique de Tunisie (INAT), and ANR-ALMIRA project is acknowledged. Climatic data and land use maps were gratefully made available by the Mediterranean Observatory of Rural Environment and Water (OMERE).

\section{References}

Adam M, Van Bussel LGJ, Leffelaar PA, Van Keulen H, Ewert F (2011) Effects of modelling detail on simulated crop productivity under a wide range of climatic conditions. Ecol Model 222:131-143

Alaya I, Masmoudi MM, Lagacherie P, Coulouma G, Jacob F, Ben Mechlia N (2017) Performance of Saxton and Rawls pedotransfer functions for estimating soil water properties in the Cap Bon Region-Northern Tunisia. In: Ouessar M, Gabriels D, Tsunekawa A, Evett S. (eds) Water and land security in drylands. Springer International Publishing, pp 77-85.

Aloui A, Masmoudi MM, Jacob F, Ben Mechlia N (2012) Use of the AquaCrop model for the simulation of wheat evapotranspiration in north-eastern Tunisia. Geophysical Research Abstracts vol. 14. EGU 2012-11842.

Andarzian B, Bannayan M, Steduto P, Mazraeh H, Barati ME, Barati MA, Rahnama A (2011) Validation and testing of the AquaCrop model under full and deficit irrigated wheat production in Iran. Agric Water Manag 100:1-8

Araya A, Habtu S, Hadgu KM, Kebede A, Dejene T (2010) Test of AquaCrop model in simulating biomass and yield of water deficient and irrigated barley (Hordeum vulgare). Agric Water Manag 97: 1838-1846

Ben Mechlia N, Oweis T, Masmoudi M, Mekki I, Ouessar M, Zante P, Zekri S (2008) Conjunctive use of rain and irrigation water from hill reservoirs for agriculture in Tunisia. On farm water husbandry research report No 6, ICARDA, Aleppo Syria vi +28 pp.

Ben Mechlia N, Oweis T, Masmoudi M, Khatteli H Ouessar M Sghaier N, Anane M, Sghaier M (2009) Assessment of supplemental irrigation and water harvesting potential: methodologies and case studies from Tunisia. ICARDA, Aleppo, Syria. iv + $36 \mathrm{pp}$.

Ben Slimane A (2013) Rôle de l'érosion ravinaire dans l'envasement des retenues collinaires dans la Dorsale tunisienne et le Cap Bon. PhD Thesis, Montpellier SupAgro, France

Bocchiola D, Nana E, Soncini A (2013) Impact of climate change scenarios on crop yield and water footprint of maize in the Po valley of Italy. Agric Water Manag 116:50-61

Boudhina N, Masmoudi MM, Alaya I, Jacob F, Ben Mechlia N (2019) Use of AquaCrop model for estimating crop evapotranspiration and biomass production in hilly topography. Arab J Geosci 12(259). https://doi.org/10.1007/s12517-019-4434-9

Brisson N, Gary C, Justes E, Roche R, Mary B, Ripoche D, Zimmer D, Sierra J, Bertuzzui P, Burger P, Bussiere F, Cabidoche YM, Cellier P, Debaeke P, Gaudillere JP, Maraux F, Seguin B, Sinoquet H (2003) An overview of the crop model STICS. Eur J Agron 18:309-332

Brown RA, Rosenberg NJ (1997) Sensitivity of crop yield and water use to change in a range of climatic factors and $\mathrm{CO} 2$ concentrations: a 
simulation study applying EPIC to the Central United States. Agric For Meteorol 83:171-203

Butcher JB, Johnson TE, Nover D, Sarkar S (2014) Incorporating the effects of increased atmospheric $\mathrm{CO} 2$ in watershed model projections of climate change impacts. J Hydrol 513:322-334

Butterworth MH, Semenov MA, Barnes A, Moran D, West JS, Fitt BDL (2010) North-South divide: contrasting impacts of climate change on crop yields in Scotland and England. J R Soc Interface 7:123-130

Campbell BM, Vermeulen SJ, Aggarwal PK, Corner-Dolloff C, Girvetz E, Loboguerrero AM, Ramirez-Villegas J, Rosenstock T, Sebastian L, Thornton P, Wollenberg E (2016) Reducing risks to food security from climate change. Glob Food Sec 11:34-43

Dechmi F, Burguete J, Skhiri A (2012) SWAT application in intensive irrigation systems: model modification, calibration and validation. $\mathrm{J}$ Hydrol 470-471(2012):227-238

Demetriou D (2014) The development of an integrated planning and decision support system for land consolidation. Dissertation. University of Leeds

El Mokh F, Vila-Garcia M, Nagaz K, Masmoudi MM, Ben Mechlia N, Fereres E (2017) In: Ouessar M, Gabriels D, Tsunekawa A, Evett S (eds) Water and land security in drylandsCalibration of AquaCrop salinity stress parameters for barley under different irrigation regimes in a dry environment. Springer International Publishing, pp $43-55$

Ewert F, Rotter RP, Bindi M, Webber H, Trnka M, Kersebaum KC, Olesen JE, Van Ittersum MK, Janssen S, Rivington M, Semenov MA, Wallach D, Porter JR, Stewart D, Verhagen J, Gaiser T, Palosuo T, Tao F, Nendel C, Roggero PP, Bartosova L, Asseng S (2015a) Crop modelling for integrated assessment of risk to food production from climate change. Environ Model Softw 72:287-303

Ewert F, van Bussel L, Zhao G, Hoffmann H et al (2015b) Uncertainties in scaling-up crop models for large area climate change impact assessments. In: Rosenzweig C, Hillel D (eds) Handbook of climate change and agroecosystems: the Agricultural Model Intercomparison Project (AgMIP). World Scientific Publishing Company, pp 262-277

Farina R, Seddaiu G, Orsini R, Steglich E, Roggero PP, Francaviglia R (2011) Soil carbon dynamics and crop productivity as influenced by climate change in a rainfed cereal system under contrasting tillage using EPIC. Soil Tillage Res 112:36-46

Faramarzi M, Yang H, Schulinc R, Abbaspoura KC (2010) Modeling wheat yield and crop water productivity in Iran: implications of agricultural water management for wheat production. Agric Water Manag 97:1861-1875

Fereres E, Walker S, Heng LK, Hsiao TC, Steduto T, Raes D, Izzi G, Asseng S, Evett SR (2012) AquaCrop applications. In: Steduto P, Hsiao TC, Fereres E, Raes D (eds) Crop yield response to water. FAO Irrigation and Drainage Paper, vol 66. FAO, Rome, pp 50-69

Fischer G, Shah M, Tubiello FN, van Velhuizen H (2005) Socioeconomic and climate change impacts on agriculture: an integrated assessment, 1990-2080. Philos Trans R Soc Lond Ser B Biol Sci 360:2067-2083

Foster T, Brozović N, Butler AP, Neale CMU, Raes D, Steduto P, Fereres E, Hsiao TC (2017) AquaCrop-OS: an open source version of FAO's crop water productivity model. Agric Water Manag 181: $18-22$

Geri F, Amici V, Rocchini D (2010) Human activity impact on the heterogeneity of a Mediterranean landscape. Appl Geogr 30:370-379

Giannakopoulos C, Le Sager P, Bindi M, Moriondo M, Kostopoulou E, Goodess CM (2009) Climatic changes and associated impacts in the Mediterranean resulting from a $2{ }^{\circ} \mathrm{C}$ global warming. Glob Planet Chang 68:209-224

Han C, Zhang B, Chen H, Wei Z, Liu Y (2019) Spatially distributed crop model based on remote sensing. Agric Water Manag 218:165-173

Hansen JW, Jones JW (2000) Scaling-up crop models for climate variability application. Agric Syst 65:43-72
Heng LK, Hsiao TC, Evett S, Howell T, Steduto P (2009) Validating the FAO AquaCrop model for irrigated and water deficient field maize. Agron J 101(2009):488-498. https://doi.org/10.2134/agronj2008. 0029xs

Hoffmann H, Zhao G, Asseng S, Bindi M, Biernath C, Constantin J, Coucheney E, Dechow R, Doro L, Eckersten H, Gaiser T, Grosz B, Heinlein F, Kassie BT, Kersebaum KC, Klein C, Kuhnert M, Lewan E, Moriondo M, Nendel C, Priesack E, Raynal H, Roggero PP, Rötter RP, Siebert S, Specka X, Tao F, Teixeira E, Trombi G, Wallach D, Weihermüller L, Yeluripati J, Ewert F (2016) Impact of spatial soil and climate input data aggregation on regional yield simulations. PLoS One 11:1-23. https://doi.org/10.1371/journal. pone. 0151782

Holzkämper A, Calanca P, Honti M, Fuhrer J (2015) Projecting climate change impacts on grain maize based on three different crop model approaches. Agric For Meteorol 214-215:219-230

Hoogenboom G, Tsuji GY, Jones JW, Singh U, Godwin DC, Pickering NB, Curry RB (1995) Decision support system to study climate change impacts on crop production. In: Rosenzweig C, Allen LH, Harper LA, Hollinger SE, Jones JW (eds) Climate change and agriculture: analysis of potential international impacts. ASA Special Publication No 59, Madison, pp 51-75

Hsiao TC, Heng L, Steduto P, Rojas-Lara B, Raes D, Fereres E (2009) AquaCrop-the FAO crop model to simulate yield response to water: III. Parameterization and testing for maize. Agron J 101:448-459

Huang F, Li B (2010) Assessing grain crop water productivity of China using a hydro-model-coupled-statistics approach: part I: method development and validation. Agric Water Manag 97(7):1077-1092. https://doi.org/10.1016/j.agwat.2010.02.016

IAO (2002) Land resources of the Oued Lebna catchment (Tunisia). 20th course professional Master "Remote sensing and natural resources evaluation", Istituto Agronomico per l'Oltremare, vol 132, Florence-Italy

Inoubli N, Raclot D, Mekki I, Moussa R, Le Bissonnais Y (2017) A spatiotemporal multiscale analysis of runoff and erosion in a Mediterranean marly catchment. Vadose Zone J 16:1-12. https:// doi.org/10.2136/vzj2017.06.0124

Jin X, Kumar L, Li Z, Xu X, Yang G, Wang J (2016) Estimation of winter wheat biomass and yield by combining the AquaCrop model and field hyperspectral data. Remote Sens 8:972

Kang Y, Khan S, Ma X (2009) Climate change impacts on crop yield, crop water productivity and food security - a review. Prog Nat Sci 19:1665-1674

Kim D, Kaluarachchi J (2015) Validating FAO AquaCrop using Landsat images and regional crop information. Agric Water Manag 149: $143-155$

Largani AS (2013) Modelling regional land use : The quest for appropriate method. $\mathrm{PhD}$ thesis, Wageningen University

Leclere D, Jayet PA, Noblet-Ducoudre N (2013) Farm-level autonomous, adaptation of European agricultural supply to climate change. Ecol Econ 87:1-14

Lorite IJ, García-Vilab M, Santos C, Ruiz-Ramos M, Fereres E (2013) AquaData and AquaGIS: two computer utilities for temporal and spatial simulations of water-limited yield with AquaCrop. Comput Electron Agric 96:227-237

Lorite IJ, Garcia-Vila M, Fereres E (2015) AquaCrop-GIS version 2.1 Reference Manual, Food and Agriculture Organization of the United Nations, vol 18, FAO Rome, Italy

Mainuddin M, Kirby M, Hoanh CT (2011) Adaptation to climate change for food security in the lower Mekong Basin. Food Sec 3:433-450. https://doi.org/10.1007/s12571-011-0154-z

Mekki I (2003) Analyse et modélisation de la variabilité des flux hydriques à l'échelle d'un bassin versant cultivé alimentant un lac collinaire du domaine semi-aride méditerranéen (Oued Kamech, Cap Bon, Tunisie). PhD. Dissertation, Montpellier II University, France $173 \mathrm{pp}$. 
Mekki I, Zitouna-Chebbi R, Jacob F, Ben Mechlia N, Prevot L, Albergel J, Voltz M (2018) Impact of land use on soil water content in a hilly rainfed agrosystem: a case study in the cap bon peninsula in Tunisia. Agrofor Int J 3:64-75

Mitter H, Heumesser C, Schmid E (2015) Spatial modeling of robust crop production portfolios to assess agricultural vulnerability and adaptation to climate change. Land Use Policy 46:75-90

Morschel (2010) L'eau et les paysages dans la dorsale Tunisienne: Expliquer le cheminement des flux hydriques en fonction des organisations présentes dans le milieu naturel. Nice Sophia Antipolis University, France, $\mathrm{PhD}$. Dissertation

OMERE (2017) The Mediterranean Observatory of Rural Environment and Water. (http://www.obs-omere.org), accessed January 2017.

Panday SG (2014) Use of remote sensing data in a crop growth model to estimate actual crop yields: testing AquaCrop with NDVI time series for two crops in Spain. Master Dissertation, Twenty University

Parry M, Rosenzweig C, Livermore M (2005) Climate change, global food supply and risk of hunger. Philos Trans R Soc B 360:21252138

R Core Team (2016) R: a language and environment for statistical computing. R Foundation for Statistical Computing, Vienna, Austria https://www.R-project.org/

Raes D, Steduto P, Hsiao TC, Fereres E (2009) AquaCrop - the FAO crop model to simulate yield response to water. II. Main algorithms and software description. J Agron 101:438-447

Rosenzweig C, Parry ML (1994) Potential impact of climate-change on world food-supply. Nature 367:133-138

Rosenzweig C, Wilbanks TJ (2010) The state of climate change vulnerability, impacts, and adaptation research: strengthening knowledge base and community. Clim Chang 100:103-106

Sala OE, Chapin FS, Armesto JJ, Berlow E, Bloomfield J, Dirzo R, Huber-Sanwald E, Huenneke LF, Jackson RB, Kinzig A, Leemans R, Lodge DM, Mooney HA, Oesterheld M, Poff NL, Sykes MT, Walker BH, Walker M, Wall DH (2000) Global biodiversity scenarios for the year 2100. Science 287:1770-1774

Saxton KE, Rawls WJ (2006) Soil water characteristic estimates by texture and organic matter for hydrologic solutions. Soil Sci Soc Am J 70:1569-1578

Schierhorn F, Faramarzi M, Prishchepov A.V, Koch F.J, Müller D (2014) Quantifying yield gaps in wheat production in Russia. Environ Res Lett. 9 084017, 12 pp, https://doi.org/10.1088/1748-9326/9/8/ 084017.

Scholten H (2008) Better modelling practice: an ontological perspective on multidisciplinary, model-based problem solving. PhD. Dissertation. Wageningen University, the Netherlands

Sghaier N, Masmoudi MM, Ben Mechlia N (2014) Paramétrage du modèle AquaCrop pour la simulation de la culture du blé dur. Revue des Régions Arides 35:1351-1360

Soil Survey Staff (1951) Soil texture. In: Soil Survey Staff (Ed.), Soil Survey Manual, United States Department of Agriculture Handbook, United States Government Printing Office, Washington DC, pp 205-213.

Steduto P, Hsiao TC, Raes D, Fereres E (2009) Aqua-Crop the FAO crop model to simulate yield response to water: I. Concepts and underlying principles. Agron J 101:426-437
Stöckle CO, Steve AM, Campbell GS (1994) CropSyst: a cropping system simulation model: water/nitrogen budgets and crop yield. Agric Syst 46:335-359

Sys I, Van Ranst E, Debaveye J (1991) Land evaluation, part II) Methods in land evaluation. Agriculture Publication no 7. General Administration for Development Cooperation, Brussels, Belgium, pp 70-76

Tubiello FN, Donatelli M, Rosenzweig C, Stöckle CO (2000) Effects of climate change and elevated $\mathrm{CO} 2$ on cropping systems: model predictions at two Italian locations. Eur J Agron 13:179-189

Tubiello FN, Ewert F (2002) Simulating the effects of elevated CO2 on crops: approaches and applications for climate change. Eur J Agron 18:57-74

Van Bussel LGJ (2011) From field to globe: upscaling of crop growth modelling. PhD. Dissertation, Wageningen University, the Netherlands.

Van Gaelen H (2016) Evaluation of agricultural management from field to catchment scale: development of a parsimonious agrohydrological model. PhD. Dissertation, KU Leuven University, Belgium.

Vanuytrecht E, Raes D, Steduto P, Hsiao TC, Fereres E, Heng LK, Vila MG, Moreno PM (2014) AquaCrop: FAO'S crop water productivity and yield response model. Environ Model Softw 62:351-360. https://doi.org/10.1016/j.envsoft.2014.08.005

Voloudakis D, Karamanos A, Economou G, Kalivas D, Vahamidis P, Kotoulas V, Kapsomenakis J, Zerefos C (2015) Prediction of climate change impacts on cotton yields in Greece under eight climatic models using the AquaCrop crop simulation model and discriminant function analysis. Agric Water Manag 147:116-128

Webber H, Gaiser T, Ewert F (2014) What role can crop models play in supporting climate change adaptation decisions to enhance food security in Sub-Saharan Africa? Agric Syst 127:161-177

White JW, Hoogenboom G, Kimball BA, Wall GW (2011) Methodologies for simulating impacts of climate change on crop production. Field Crop Res 124:357-368

Williams JR, Jones CA, Dyke PT (1984) A modeling approach to determining the relationship between erosion and soil productivity. Transaction of the ASAE 27:129-144

Willmott CJ (1981) On the validation of models. Phys Geogr 2:184-194

Yin X (2013) Improving ecophysiological simulation models to predict the impact of elevated atmospheric $\mathrm{CO} 2$ concentration on crop productivity. Ann Bot 112:465-475

Yuan M, Zhang L, Gou F, Su Z, Spiertz JHJ, van der Werf W (2013) Assessment of crop growth and water productivity for five $\mathrm{C} 3$ species in semi-arid Inner Mongolia. Agric Water Manag 122:28-38

Zante P, Collinet J, Pepin Y (2005) Caractéristiques pédologiques et hydro-météorologiques du bassin versant de Kamech, Cap Bon, Tunisie. UMR LISAH IRD Tunis, DG ACTA Direction des Sols Tunis. INRGREF, Tunis

Zitouna-Chebbi R, Prévot L, Chakhar A, Marniche- Ben Abdallah M, Jacob F, 2018 Observing actual evapotranspiration from flux tower eddy covariance measurements within a hilly watershed: case study of the Kamech site, Cap Bon Peninsula, Tunisia. Atmosphere 9: 68. DOI https://doi.org/10.3390/atmos90200680. 